Article

\title{
Why Should We Protect the Interests of "Green Food" Certified Product Growers? Evidence from Kiwifruit Production in China
}

\author{
Ruifeng Liu ${ }^{1} \mathbb{D}$, Zhifeng Gao ${ }^{2}$, Gongan Yan ${ }^{1}$ and Hengyun Ma ${ }^{1, * \mathbb{C}}$ \\ 1 College of Economics and Management, Henan Agricultural University, Zhengzhou 450046, China; \\ ruifeng076@163.com (R.L.); yangongan113@163.com (G.Y.) \\ 2 Food and Resource Economics Department, University of Florida, P.O. Box 110240, Gainesville, FL 32611, \\ USA; zfgao@ufl.edu \\ * Correspondence: h.y.ma@163.com; Tel.: +86-371-5699-0018
}

Received: 27 November 2018; Accepted: 14 December 2018; Published: 15 December 2018

\begin{abstract}
Governments and nongovernmental organizations (NGOs) have promoted environmental and social certification programs for growers because the market for green certification is seen as offering higher prices and higher incomes. Previous studies have examined how "green food" certification affects economic and environmental benefits, but none have studied its impact on production behavior. In this study we conducted a household survey of 398 randomly selected growers of traditional and green food certified kiwifruit in Xixia county of Henan province, China. The results show that characteristically, green food certified growers can have a significantly higher total cost as well as employed cost compared to the matched noncertified growers. Based on the results, we conclude the potential advantages of green food certified kiwifruit products and basic conditions for its sustainable development.
\end{abstract}

Keywords: "green food" certification; household behavior; potential advantage; kiwifruit

\section{Introduction}

Farmers are seeking sustainable agriculture because of concerns about deteriorating environmental health, growing demand from consumers and importers for improved food safety and quality products, and opportunities for high returns [1,2]. In 1989-1990, the "green food" certification scheme was launched and popularized by the Chinese government in order to alleviate the serious impact of intensive management on the ecological environment and explore the agricultural mode suitable for the sustainable development of Chinese agriculture [3,4]. At present, the certification and monitoring of green food is carried out by a government agency, the China Green Food Development Center under the auspices of the Ministry of Agriculture and Rural Affairs of China, where green food is officially defined as: "Under strict supervision, control and regulation in production, processing, packing, storage and transportation, green food adopts the wholesome quality control from field to table, while it requires reasonable applications of inputs, including pesticide, fertilizer, veterinary drug and additive etc. to prevent any pollution of toxic and harmful matters to produce and links in food processing so as to ensure environmental and product safety" [5]. As a result, the numbers of both certified firms and products have steadily increased [6]. On the other hand, in the past 5-10 years, the domestic market for high-quality products, such as organic and green foods, has boomed and outweighed the export market $[1,3,6]$. It is a reflection of that increase in the safety and quality of food [7], and the enhancement of the purchasing power of the upper strata of China [1]. A few but a growing number of middle- and upper-class consumers have been willing to pay a high price in the rapid growth of the organic and green foods niche market [8-11]. 
A growing body of literature has examined the effects of certification standards on a variety of indicators, such as those of economics (yields, costs, gross incomes, and net profits), environment (chemical input, organic fertilizer, and soil conservation practices), and ecology (tree, mammal, bird, and butterfly species) [12-19]. However, existing studies on the grower-level effects of certification are limited and the results are mixed. Some studies showed that sustainable certifications not only significantly improve farmers' income and living standards (e.g., [20,21]), but also improve farmers' environmental performance (e.g., $[15,19,22,23]$. But some research demonstrated that certification (e.g., UTZ or organic certification) had no (or limited) potential to increase income and production $[13,24]$. Beuchelt and Zeller noted that organic and fairtrade certified producers are more often found below the absolute poverty line than conventional growers [25]. Furthermore, some scholars demonstrated that growers are reluctant to adopt green or organic agriculture due to perceived lower yields and higher production costs in China and throughout the world [2,6,26,27]. The high production cost of green food, coupled with the distrust of consumers in the market, makes it difficult for green food products to achieve high quality and high prices, resulting in Chinese farmers' indifference to the green food production [6].

These findings suggest that economic and environmental effects may vary due to a variety of factors, including regional context and standard types. Therefore, general conclusions about the impacts of sustainable standards on smallholder farmers are not justified. To gain further insight, examining effects of different types of sustainable standards in the different regional contexts would be useful. This paper contributes to fill the gap with an empirical study to analyze the impacts of the unique green food certification scheme on smallholder kiwifruit growers in China against a control group of noncertified kiwifruit growers. Rather than simply focusing on the final economic or environmental outcome of green food production, we focus on the impact of green food certification on various aspects of the production system, such as the yield, cost, price, and so forth. Our studies will provide quantitative evidence to decision makers who are currently supporting or going to support the green food certification programs as tools to increase growers' income and develop green agriculture. (Green food certification in China can be classified into two different levels: Grade A and Grade AA [28]. Grade A green food is allowed limited use of limited chemical synthetic production materials, while Grade AA green food (equivalent to organic food) is absolutely not allowed to use chemically synthesized fertilizers, pesticides, veterinary drugs, fish drugs, additives, etc. In June 2008, Grade AA green food was suspended officially by the China Green Food Development Center. Therefore, Grade A green food certification is analyzed in this paper.) We provide answers to the research question: What are the potential advantages of green food certified kiwifruit production and basic conditions for its sustainable development?

To answer these questions, we propose and empirically test the following four economic hypotheses for green food certified kiwifruit production behavior:

Hypothesis 1. The yield of green food certified kiwifruit is lower than that of noncertified kiwifruit. Generally, green food certified kiwifruit has less input in planting materials. In particular, the green food production guideline calls for reducing or banning the use of pesticides and chemical fertilizers. (As one of the reviewers suggested, the money-based chemical inputs cannot necessarily reflect the quantity of chemical inputs proportionally given the less-polluting, new-generation pesticides are often more expensive than the usual ones. To avoid the misleading of the money-based chemical input indicators, we asked kiwifruit growers for traditional and the most popular chemical fertilizers and pesticides, rather than the more expensive and less-polluting, new-generation ones. Therefore, we use the money-based chemical inputs as an approximation of chemical fertilizers and pesticides given the availability of data in this study. In addition, in this paper, we do not use it as an ecological indicator. What we want to show readers is how much chemical fertilizers and pesticide can be reduced for green food certification.) Therefore, the output of green food certified kiwifruit is expected to be lower than that of noncertified kiwifruit. However, this hypothesis suggests that green food certified kiwifruit farming may have great potential to increase yield compared with noncertified farming. The yield of green food 
certified kiwifruit production is low but may indicate its higher marginal yield. In other words, the marginal cost of green food certified kiwifruit production may be less than the marginal cost of noncertified kiwifruit production.

Hypothesis 2. The production cost per mu (1 hectare $=15 \mathrm{mu}$ (Chinese)) of green food certified kiwifruit is higher than that of noncertified kiwifruit. Less chemical fertilizer and pesticide are used in the green food certified kiwifruit production process, and meanwhile green food certified kiwifruit requires more labor and farmyard manure. This could eventually lead to higher input costs for green food certified kiwifruit than for noncertified kiwifruit products. This is the necessary condition for the sustainable development of green food certified kiwifruit growers.

Hypothesis 3. The green food certified kiwifruit is expected to have a higher farm-gate price due to its higher quality because of less chemical fertilizer and pesticide inputs than conventional ones. These higher prices are needed to cover the additional costs of green food participation schemes and lead to net increases in per mu kiwifruit income as compared to noncertified growers.

Hypothesis 4. Green food certified kiwifruit farming is supposedly more environmentally friendly than the noncertified kiwifruit production: more farmyard manure may be used, while less chemical fertilizer and pesticides are applied as certification scheme required.

The next two sections describe the methods used and the data collection process, respectively. This is followed by the results and discussion, before conclusions regarding the economic results and environmental effects of the green food certification scheme. In addition, the potential advantages and sustainable conditions for the cultivation of green kiwifruit conditions are drawn.

\section{Methodology}

\subsection{Modeling the Impact of Certification}

To evaluate the impact of certification, we apply the propensity score matching (PSM) method to control for selection bias. We do so since the observed effect of green certification schemes may be undermined by selection effects $[15,23]$, where growers already meeting certification criteria tend to disproportionately obtain certification [29]. Certified growers have strong incentives to opt into certification schemes because they do not need to make additional investments or change production practices to satisfy necessary criteria [30]. An evaluation that failed to control for such selection bias would conflate the effects of certification on outcomes with the effects of pre-existing differences between certified and noncertified growers [23]. When applying the PSM method, we also test the sensitivity of estimates to potential hidden biases.

In theory, the impacts of a certification scheme should be evaluated by estimating the average treatment effect on the treated (ATT), which is specified as follows:

$$
E\left(W_{i} \mid D_{i}=1\right)=E\left(Y_{i}(1) \mid D_{i}=1\right)-E\left(Y_{i}(0) \mid D_{i}=1\right)
$$

where $W_{i}$ denotes the unbiased effect for grower $i$ that participates in the certification scheme, $i=1$. $Y_{i}(1)$ is the outcome variable with certification, while $Y_{i}(0)$ is the outcome variable if the same growers are not certified. $D_{i}$ is a dummy variable indicating whether grower $i$ participates in the certification scheme $\left(D_{i}=1\right.$ means the grower participates in the certification scheme; $D_{i}=0$ means the grower does not).

However, the same growers are not observed with and without certification [21]. Therefore, one has to compare certified and noncertified growers that are not identical, as follows:

$$
E\left(W_{i} \mid D_{i}=1\right)=E\left(Y_{i}(1) \mid D_{i}=1\right)-E\left(Y_{i}(0) \mid D_{i}=0\right)
$$


where $E\left(Y_{i}(0) \mid D_{i}=0\right)$ is the outcome for growers not participating in the certification. However, when there is a difference in the observed or unobserved characteristics between a certified grower and a noncertified grower, Equation (2) will lead to a skewed effect, and the deviation $B$ can be expressed as:

$$
B=E\left(Y_{i}(0) \mid D_{i}=1\right)-E\left(Y_{i}(0) \mid D_{i}=0\right)
$$

One of the appropriate ways to avoid estimating the deviation is to randomly assign the grower to the control group and treatment group, thereby ensuring there is no system difference between the two groups [21]. In our study, random assignment was not possible. Therefore, in evaluating the impact of the green food certification scheme, the PSM method was used to reduce selection bias.

\subsection{Propensity Score Matching}

We first estimate the probability of grower $i$ participating in a green food certification scheme using a Probit model. That is, we estimate:

$$
\operatorname{Prob}\left(D_{i}=1\right)=F\left(Z_{i}\right)
$$

where $F\left(Z_{i}\right)$ is the predicted conditional p-score of a grower participating in a green food certification scheme. $Z_{i}$ is a rich set of grower and farm characteristics including Age (the age of the grower in years), Education (the highest grade completed), Labor (the number of household labor), and Average area (the per capita cultivated area of the family). The farm characteristics, all of which correspond to the year we conducted the survey, are Treeage (the age of kiwifruit trees), Soiltype (a dichotomous dummy variable equal to one if the soil type of the farm is sandy, versus clay or loam); and Terrain (a dichotomous dummy variable equal to one if the terrain of the farm is plain, versus mountain or hills).

The PSM estimator is simply the mean difference in outcomes over the common support, which is appropriately weighted by the p-score. Following Rosenbaum and Rubin [31], estimation of ATT can be represented as:

$$
A T T=\mathrm{E}\left(Y_{i}(1) \mid D_{i}=1, \mathrm{P}\left(Z_{i}\right)\right)-\mathrm{E}\left(Y_{i}(0) \mid D_{i}=0, \mathrm{P}\left(Z_{i}\right)\right)
$$

where ATT is simply the difference between the mean outcomes for the sample of green food certified growers and a matched sample of noncertified growers selected using p-scores. In our case, the six economic outcome variables are Total revenue, Total cost, Net income, Sale price, Average yield, and Employee cost. Total revenue is valued as gross output per mu. Total cost is the sum of labor cost and physical input costs per mu. (The standard of green food certification and labeling fee is 8000 yuan per product in China, which was borne by the local government in our case. Regarding technical advice for the green food, we also observed that the government encouraged farmers to carry out green food certification. The government regularly sent technicians to teach certified farmers about green food planting for free. Therefore, in our study, neither the certification cost nor the technical advice cost was included in the total cost.) Net income is the difference between total revenue and total production cost per mu. Sale price is the market price for selling kiwifruit. Average yield is the average yield per mu of the kiwifruit. Employee cost is estimated by summing the cost of hired labor. The three environmental input variables are Farmyard manure, Chemical fertilizer, and Pesticide, which represent input costs per $\mathrm{mu}$, and are estimated using input prices and quantities reported by the grower (Table 1).

To match the treatment and control groups, nearest neighbor 1-to-1 matching method with replacement, whereby each certified grower is matched to the noncertified grower with the closest p-score, was employed. Using PSM to calculate standard errors for ATT estimates is not straightforward, since these errors should account for the fact that p-scores are used for estimation of common support [32]. Therefore, following Lechner [33] and Dehejia and Wahba [34], bootstrapping with 500 replications is applied to estimate the standard errors in our case. 
Furthermore, it should be emphasized that the PSM is based on the Conditional Independence Assumption (CIA), which is also known as "selection on observables" [31]. This means that the method only controls for observed heterogeneity between control and treatment growers. Thus, when heterogeneity is not observed, the estimate of the ATT may still have a deviation. Following DiPrete and Gangl [35] and Becker and Caliendo [36], we calculate Rosenbaum bounds to test for the effect of the hidden bias.

Table 1. Variables, definitions, means, and difference-in-means tests.

\begin{tabular}{|c|c|c|c|c|c|}
\hline Variable & Definition & $\begin{array}{c}\text { Mean All } \\
(n=398)\end{array}$ & $\begin{array}{l}\text { Certified } \\
(n=57)\end{array}$ & $\begin{array}{l}\text { Noncertified } \\
(n=341)\end{array}$ & $\begin{array}{c}t \text {-Test } \\
\text { Diffmeans }\end{array}$ \\
\hline \multicolumn{6}{|l|}{ Treatment: } \\
\hline Certified green food & $\begin{array}{l}\text { Certified } \\
(1=\text { yes, } 0=\text { no })\end{array}$ & $\begin{array}{l}0.14 \\
(0.4)\end{array}$ & - & - & - \\
\hline \multicolumn{6}{|c|}{ Economic outcomes: } \\
\hline Total revenue & $\begin{array}{l}\text { Gross output value } \\
\text { (yuan/mu) }\end{array}$ & $\begin{array}{l}2792.15 \\
(2702.9)\end{array}$ & $\begin{array}{l}3090.81 \\
(2827.9) \\
\end{array}$ & $\begin{array}{l}2742.23 \\
(2682.5)\end{array}$ & 348.57 \\
\hline Total cost & $\begin{array}{l}\text { Total cost } \\
\text { (yuan/mu) }\end{array}$ & $\begin{array}{l}1164.23 \\
(685.7)\end{array}$ & $\begin{array}{l}1238.46 \\
(626.9)\end{array}$ & $\begin{array}{l}1151.82 \\
(695.1)\end{array}$ & 86.64 \\
\hline Net income & $\begin{array}{l}\text { Net income } \\
\text { (yuan/mu) }\end{array}$ & $\begin{array}{l}1627.93 \\
(2522.9) \\
\end{array}$ & $\begin{array}{l}1852.34 \\
(2623.5) \\
\end{array}$ & $\begin{array}{l}1590.41 \\
(2507.7) \\
\end{array}$ & 261.93 \\
\hline Sales price & $\begin{array}{l}\text { Average price } \\
\text { (yuan } / \mathrm{kg} \text { ) }\end{array}$ & $\begin{array}{l}3.73 \\
(2.5)\end{array}$ & $\begin{array}{l}4.18 \\
(2.5)\end{array}$ & $\begin{array}{l}3.65 \\
(2.5)\end{array}$ & $0.526^{* *}$ \\
\hline Average yield & $\begin{array}{l}\text { Average yield } \\
(\mathrm{kg} / \mathrm{mu})\end{array}$ & $\begin{array}{l}709.76 \\
(621.5)\end{array}$ & $\begin{array}{l}631.45 \\
(448.8)\end{array}$ & $\begin{array}{l}722.85 \\
(645.4)\end{array}$ & $-91.41 *$ \\
\hline Employee cost & $\begin{array}{l}\text { Employed labor } \\
\text { (yuan/mu) }\end{array}$ & $\begin{array}{c}29.46 \\
(119.0)\end{array}$ & $\begin{array}{c}77.42 \\
(218.9)\end{array}$ & $\begin{array}{l}21.45 \\
(90.5)\end{array}$ & $55.97^{* *}$ \\
\hline \multicolumn{6}{|c|}{ Environ. outcomes: } \\
\hline Farmyard manure & $\begin{array}{l}\text { Input cost } \\
\text { (yuan/mu) }\end{array}$ & $\begin{array}{l}125.79 \\
(237.5)\end{array}$ & $\begin{array}{l}157.97 \\
(280.6)\end{array}$ & $\begin{array}{l}120.42 \\
(229.5)\end{array}$ & 37.56 \\
\hline Chemical fertilizer & $\begin{array}{l}\text { Input cost } \\
\text { (yuan /mu) }\end{array}$ & $\begin{array}{l}595.84 \\
(415.9)\end{array}$ & $\begin{array}{l}589.20 \\
(370.4)\end{array}$ & $\begin{array}{l}596.96 \\
(423.5)\end{array}$ & -7.76 \\
\hline Pesticide & $\begin{array}{l}\text { Input cost } \\
\text { (yuan/mu) }\end{array}$ & $\begin{array}{l}69.84 \\
(62.2)\end{array}$ & $\begin{array}{l}61.81 \\
(45.0)\end{array}$ & $\begin{array}{l}71.19 \\
(64.6) \\
\end{array}$ & $-9.38 *$ \\
\hline \multicolumn{6}{|c|}{ Control household: } \\
\hline Age of head & Years & $\begin{array}{l}53.26 \\
(10.6) \\
\end{array}$ & $\begin{array}{l}53.47 \\
(9.9) \\
\end{array}$ & $\begin{array}{l}53.23 \\
(10.7) \\
\end{array}$ & 0.25 \\
\hline Education of head & Schooling years & $\begin{array}{l}7.35 \\
(3.1) \\
\end{array}$ & $\begin{array}{l}7.72 \\
(2.3) \\
\end{array}$ & $\begin{array}{l}7.29 \\
(3.2) \\
\end{array}$ & 0.43 \\
\hline Labor & Number of labor & $\begin{array}{r}3.26 \\
(1.04) \\
\end{array}$ & $\begin{array}{c}3.32 \\
(1.12) \\
\end{array}$ & $\begin{array}{c}3.25 \\
(1.04) \\
\end{array}$ & 0.06 \\
\hline Average area & $\begin{array}{l}\text { Cultivated area } \\
\text { (mu per capita) }\end{array}$ & $\begin{array}{l}0.63 \\
(0.5) \\
\end{array}$ & $\begin{array}{l}0.77 \\
(0.8)\end{array}$ & $\begin{array}{l}0.60 \\
(0.5) \\
\end{array}$ & $0.17^{* *}$ \\
\hline \multicolumn{6}{|l|}{ Farm: } \\
\hline Tree age & Year of kiwifruit tree & $\begin{array}{l}6.84 \\
(3.5) \\
\end{array}$ & $\begin{array}{l}6.39 \\
(2.8) \\
\end{array}$ & $\begin{array}{l}6.92 \\
(3.7) \\
\end{array}$ & $-0.53 *$ \\
\hline Soil type & $\begin{array}{l}\text { Sandy } \\
(1=\text { yes, } 0=\text { no })\end{array}$ & $\begin{array}{l}0.77 \\
(0.4)\end{array}$ & $\begin{array}{l}0.95 \\
(0.2)\end{array}$ & $\begin{array}{l}0.73 \\
(0.4) \\
\end{array}$ & $0.21 * * *$ \\
\hline Terrain & $\begin{array}{l}\text { Plain } \\
(1=\text { yes, } 0=\text { no })\end{array}$ & $\begin{array}{l}0.68 \\
(0.5)\end{array}$ & $\begin{array}{l}0.96 \\
(0.2)\end{array}$ & $\begin{array}{l}0.63 \\
(0.5)\end{array}$ & $0.34^{* * *}$ \\
\hline
\end{tabular}


Table 1. Cont.

\begin{tabular}{|c|c|c|c|c|c|}
\hline Variable & Definition & $\begin{array}{l}\text { Mean All } \\
(n=398)\end{array}$ & $\begin{array}{l}\text { Certified } \\
(n=57)\end{array}$ & $\begin{array}{c}\text { Noncertified } \\
(n=341)\end{array}$ & $\begin{array}{c}t \text {-Test } \\
\text { Diffmeans }\end{array}$ \\
\hline \multicolumn{6}{|c|}{ Cobb-Douglas production and profit function: } \\
\hline Ln_aveyield & Ln (average yield) & $\begin{array}{c}5.71 \\
(2.14)\end{array}$ & $\begin{array}{c}5.62 \\
(2.20)\end{array}$ & $\begin{array}{c}5.72 \\
(2.13)\end{array}$ & -0.09 \\
\hline Ln_manure & $\begin{array}{l}\text { Ln } \\
\text { (farmyard manure cost) }\end{array}$ & $\begin{array}{c}2.23 \\
(2.67)\end{array}$ & $\begin{array}{c}2.30 \\
(2.86)\end{array}$ & $\begin{array}{c}2.22 \\
(2.64)\end{array}$ & 0.08 \\
\hline Ln_fertilizer & $\begin{array}{l}\text { Ln } \\
\text { (chemical fertilizer cost) }\end{array}$ & $\begin{array}{c}5.93 \\
(1.39)\end{array}$ & $\begin{array}{c}6.05 \\
(1.11)\end{array}$ & $\begin{array}{c}5.92 \\
(1.43)\end{array}$ & 0.13 \\
\hline Ln_pesticide & Ln (pesticide cost) & $\begin{array}{c}3.75 \\
(1.24)\end{array}$ & $\begin{array}{c}3.76 \\
(1.06)\end{array}$ & $\begin{array}{c}3.73 \\
(1.27)\end{array}$ & 0.01 \\
\hline Ln_machine & Ln (machinery cost) & $\begin{array}{c}5.08 \\
(1.28)\end{array}$ & $\begin{array}{c}5.30 \\
(1.16)\end{array}$ & $\begin{array}{c}5.04 \\
(1.30)\end{array}$ & 0.25 \\
\hline Ln_employ & Ln (employee cost) & $\begin{array}{c}0.54 \\
(1.63)\end{array}$ & $\begin{array}{c}1.02 \\
(2.25)\end{array}$ & $\begin{array}{c}0.46 \\
(1.49)\end{array}$ & $0.55^{* *}$ \\
\hline Agrimaterial store & $\begin{array}{l}\text { Number of agricultural } \\
\text { material stores }\end{array}$ & $\begin{array}{c}2.41 \\
(1.42)\end{array}$ & $\begin{array}{c}3.82 \\
(1.50)\end{array}$ & $\begin{array}{c}2.18 \\
(1.26)\end{array}$ & $1.65^{* * *}$ \\
\hline Sales channel & $\begin{array}{l}\text { Sold within the province } \\
(1=\text { yes, } 0=\text { no })\end{array}$ & $\begin{array}{c}0.39 \\
(0.49)\end{array}$ & $\begin{array}{c}0.40 \\
(0.49)\end{array}$ & $\begin{array}{c}0.39 \\
(0.49)\end{array}$ & 0.01 \\
\hline Single decision & $\begin{array}{l}\text { Single decision } \\
(1=\text { yes, } 0=\text { no })\end{array}$ & $\begin{array}{c}0.30 \\
(0.46) \\
\end{array}$ & $\begin{array}{c}0.32 \\
(0.47) \\
\end{array}$ & $\begin{array}{c}0.29 \\
(0.46) \\
\end{array}$ & 0.02 \\
\hline Technical title & $\begin{array}{l}\text { Obtain a technical title } \\
(1=\text { yes, } 0=\text { no })\end{array}$ & $\begin{array}{c}0.12 \\
(0.32)\end{array}$ & $\begin{array}{c}0.09 \\
(0.29)\end{array}$ & $\begin{array}{c}0.12 \\
(0.33)\end{array}$ & -0.03 \\
\hline
\end{tabular}

Notes: Numbers are means; numbers in parentheses are S.D. values. ${ }^{* * *}, * *$, and ${ }^{*}$ are significant at $1 \%, 5 \%$, and $10 \%$ level, respectively.

\subsection{Cobb-Douglas Production and Profit Function}

The Cobb-Douglas function is a special form of the production function obtained by American mathematician C.W. Cobb and economist P.H. Douglas, widely used to represent the technological relationship between the amounts of two or more inputs (particularly physical capital and labor) and the amount of output that can be produced by those inputs [37]. In its most standard form for production of a single good with two factors, the function is:

$$
Y=A K^{\alpha} L^{\beta}
$$

where $Y$ is the total production, $K$ is capital input, $L$ is labor input, $A$ represents a certain technical level, and $\alpha$ and $\beta$ are the output elasticities of capital and labor, respectively. These values are constants determined by available technology. In its generalized or unrestricted form, the Cobb-Douglas function models more than two goods. The Cobb-Douglas function can be written as [38]:

$$
f(x)=A \prod_{i=1}^{L} x_{i}{ }^{\lambda_{i}}, \mathrm{x}=\left(x_{1}, \cdots, x_{L}\right),
$$

where $A$ is an efficiency parameter, $L$ is the total number of goods, $x_{1}, \cdots, x_{L}$ are the (non-negative) quantities of inputs, produced, and so forth, and $\lambda_{i}$ is the elasticity parameter for input $i$.

The Cobb-Douglas function form can be estimated as a linear relationship. In our study, we extend the Cobb-Douglas function models, take the logarithm of both sides of the above formula, and introduce the variables that may shift the function, which leads to the following expression:

$$
\ln (Y)=\ln A+\sum_{i=1}^{i} \alpha_{i} \ln \left(X_{i}\right)+\sum_{k=1}^{k} \beta_{k} Z_{k}+v
$$

where $Y$ is yield per mu of kiwifruit, $X_{1}, \cdots, X_{i}$ are the input amounts of farmyard manure (Ln_manure), chemical fertilizer (Ln_fertilizer), pesticide (Ln_pesticide), machinery (Ln_macost), and the employment 
of labor per mu (Ln_employ), respectively. $Z_{1}, \cdots, Z_{k}$ are the grower's age (Age), education level (Education), per capita cultivated land area of the family (Average area), kiwifruit tree age (Tree age), the number of agricultural materials stores in the village (Agrimaterial store), and the terrain of the farm (Terrain), respectively (Table 1$). \alpha_{i}$ are the output elasticities with respect to $X_{i}$, and $v$ is the residual term.

Furthermore, in order to examine the impact of production and sales prices on profits, the profit function is set as:

$$
R=\gamma_{0}+\sum_{j=1}^{j} \gamma_{j} W_{j}+\varepsilon
$$

where $R$ represents profits per mu of kiwifruit (Net income), $\gamma_{0}$ is the constant term, $\gamma_{j}$ are the coefficients, $W_{j}$ are the factors that influence the net income per mu, including yield per mu (Average yield), sales price (Sales price), whether to be sold within the province (Sales channel), whether to join the cooperative (Cooperative), whether to make a single decision (Single decision), and whether to obtain a technical title (Technical title), respectively (Table 1). $\varepsilon$ is the residual term.

\section{Data and Descriptive Statistics}

\subsection{Data Source}

The study was conducted during July to August 2014 in Xixia county of Henan province, China. We surveyed 398 kiwifruit growers from 12 villages and 4 towns of the southeast, central, west, and north of Xixia county, including 57 green food certified growers and 341 noncertified growers. Growers were chosen randomly from a list of growers engaged in kiwifruit production. By using information from the local Bureau of Agriculture, sample districts Danshui, Wujiaqiao, Dinghe, and Chongyang in Xixia county were selected because of their high intensity of kiwifruit cultivation. We surveyed 97 kiwifruit growers in Danshui, 97 kiwifruit growers in Wujiaqiao, 101 kiwifruit growers in Dinghe, and 103 kiwifruit growers in Chongyang. The survey collected data on various aspects of the kiwifruit farm, including the characteristics of farm management, production inputs, marketing channel, and whether it had green food certification. Additionally, information on growers' characteristics was requested in our study.

\subsection{Descriptive Statistics}

The characteristics of green food certified and noncertified kiwifruit growers are shown in Table 1. We find that the difference between certified and noncertified kiwifruit growers was statistically significant in Sale price, Average yield, Employee cost, and Pesticide before matching. Regarding the economic outcomes, certified kiwifruit growers significantly received a higher sale price (4.18 yuan per $\mathrm{kg}$ ) compared to noncertified kiwifruit growers ( 3.65 yuan per kg). Similarly, we find that the certified kiwifruit growers had significantly lower yield (631.45 kg per mu (in July 2014, $1 \mathrm{USD}=6.17$ yuan $(\mathrm{RMB}))$ ) compared to noncertified kiwifruit growers (722.85 $\mathrm{kg}$ per mu). We also observe that certified kiwifruit growers significantly invested higher employee cost (77.42 yuan per mu) compared to noncertified kiwifruit growers (21.45 yuan per mu). In terms of environmental outcomes, certified kiwifruit growers significantly invested lower pesticide (61.81 yuan per mu) compared to noncertified kiwifruit growers (71.19 yuan per $\mathrm{mu}$ ). For household control variables, the certified growers had significantly larger cultivated area $(0.77 \mathrm{mu}$ per capita) than noncertified growers $(0.60 \mathrm{mu}$ per capita). The certified growers had significantly younger trees (6.39 years) compared to noncertified growers (6.92 years). Finally, it seems that the soil type and terrain of certified growers were more likely to be sandy and plain, respectively, compared to noncertified growers. With regard to variables in the Cobb-Douglas production function and profit function, the logarithm mean employee cost of certified growers (1.02) was significantly greater than that of noncertified growers (0.46). This result is consistent with the analysis of the mean employee cost of certified growers and noncertified growers in the above paragraph. We also found that the number of agricultural material stores in the area where the certified growers were located (3.82) was significantly more than that of noncertified growers (2.18). 


\section{Results and Analyses}

\subsection{Propensity Scores and Balance Tests}

Table 2 presents the odds ratio from the logit regression used to generate the propensity scores. The goodness of fit can be measured by the pseudo $R^{2}$ value, and our logit estimation gives a pseudo $\mathrm{R}^{2}$ of 0.155 . The results indicate that, all other things being equal in our sample, farms with larger per acreage, younger trees, sandy soil, and plain terrain are more likely to be certified.

Table 2. Logit regression results (dependent variable is whether farms participated in the green food certified scheme).

\begin{tabular}{lccc}
\hline \multicolumn{1}{c}{ Variable } & Coefficient & Odd Ratio & S.E. \\
\hline Household: & & & \\
Age of head & -0.00 & 0.99 & 0.01 \\
Education of head & 0.04 & 1.04 & 0.06 \\
Labor & 0.12 & 1.13 & 0.16 \\
Average area & $0.67^{* *}$ & 1.95 & 0.50 \\
\hline Farm: & & & \\
Tree age & $-0.08^{*}$ & 0.92 & 0.04 \\
Soil type & $1.27^{* *}$ & 3.55 & 2.22 \\
Terrain & $2.74^{* * *}$ & 15.53 & 11.66 \\
Constant & $-5.76^{* * *}$ & 0.00 & 0.00 \\
LR chi2 & $50.76^{* * *}$ & & \\
$p>$ chi2 & 0.0000 & & \\
Log likelihood & -138.10 & & \\
Pseudo R & 0.155 & & \\
\hline
\end{tabular}

Notes: The nearest neighbor 1-to-1 matching method with replacement was used in our study. ${ }^{* * *}, * *$, and * are significant at $1 \%, 5 \%$, and $10 \%$ level, respectively.

Table 3 shows the results of balancing tests for the PSM with the nearest neighbor 1-to-1 matching method with replacement. A $t$-test was used to compare the mean of each covariate between the treatment and control group after the matching procedure. If the matching was successfully accomplished, the mean difference after matching should be insignificant. The results of the $t$-test showed that the differences in most of the covariates became insignificant after the matching procedure, which indicates that the observable characteristics of the control group were sufficiently similar to those of the treatment group after matching.

Table 3. Results of balancing tests before and after the nearest neighbor 1-to-1 matching with replacement.

\begin{tabular}{llccccccc}
\hline \multicolumn{1}{c}{ Variable } & Sample & \multicolumn{3}{c}{ Mean } & \multicolumn{2}{c}{$t$-Test } & V(T)/V(C) \\
\hline Household & & Treated & Control & \% Bias & \% Redu. Bias & $\mathbf{t}$ & $p>|\mathbf{t}|$ & \\
Age of head & Unmatched & 53.474 & 53.229 & 2.4 & - & 0.16 & 0.872 & 0.86 \\
& Matched & 53.232 & 53.429 & -1.9 & 19.8 & -0.10 & 0.924 & 0.71 \\
Education of & Unmatched & 7.719 & 7.290 & 15.5 & - & 0.98 & 0.326 & $0.54^{*}$ \\
head & Matched & 7.768 & 7.554 & 7.8 & 50.0 & 0.46 & 0.647 & 0.77 \\
Labor & Unmatched & 3.316 & 3.252 & 5.9 & - & 0.42 & 0.672 & 1.17 \\
& Matched & 3.304 & 3.071 & 21.5 & -265.1 & 1.19 & 0.237 & 1.46 \\
Average area & Unmatched & 0.773 & 0.604 & 26.0 & - & 2.23 & 0.026 & $2.81^{*}$ \\
& Matched & 0.697 & 0.743 & -7.0 & 72.9 & -0.42 & 0.677 & 0.81 \\
\hline Farm & & & & & & & & $0.58^{*}$ \\
Tree age & Unmatched & 6.386 & 6.918 & -16.4 & - & -1.05 & 0.294 & 0.79 \\
Soil type & Matched & 6.232 & 6.179 & 1.7 & 89.9 & 0.10 & 0.917 & 0.79 \\
& Unmatched & 0.947 & 0.739 & 59.6 & - & 3.50 & 0.001 & $0.26^{*}$ \\
Terrain & Matched & 0.946 & 0.946 & 0.0 & 100.0 & -0.00 & 1.000 & 1.00 \\
& Unmatched & 0.965 & 0.628 & 92.0 & - & 5.19 & 0.000 & $0.15^{*}$ \\
& Matched & 0.964 & 0.964 & 0.0 & 100.0 & -0.00 & 1.000 & 1.00 \\
\hline
\end{tabular}

Note: ${ }^{* * *}, * *$, and $*$ are significant at $1 \%, 5 \%$, and $10 \%$ level, respectively. 
4.2. Impact of the Green Food Certification (In Our Study, Five Different Matching Algorithms Were Employed to Match the Treatment and Control Groups: Nearest Neighbor 1-to-1 Matching, Nearest Neighbor 1-to-4 Matching, Nearest Neighbor 1-to-8 Matching, Kernel Matching, and Radius Matching. However, Only Nearest Neighbor 1-to-1 Matching Result Is Reported.)

We first discuss the results for the economic outcomes and then for the environmental outcomes. Table 4 presents results for the economic outcomes (Total revenue, Total cost, Net income, Sales price, Average yield, and Employee cost) by using the nearest neighbor 1-to-1 matching method with replacement. The results provide strong evidence that green food certification has positive effects on two out of the six economic outcomes. With regard to Total cost, the standard matching ATT is positive and statistically significant, implying that, on average, the green food certified kiwifruit growers invest 331.40 yuan per mu more in total costs than matched noncertified kiwifruit growers. The results verify Hypothesis 2 in this paper. Furthermore, we find that the standard matching ATT of Employee cost is positive and statistically significant, indicating that, on average, green food certified growers invest 51.51 yuan per mu more in employee costs than matched uncertified growers. For Total revenue, Net income, Sales price, and Average yield, the ATTs are 965.08, 651.67, 0.33, and 53.27, respectively. However, the ATTs of them are not statistically significant. Furthermore, we find that the sales price of certified kiwifruit is higher than that of noncertified kiwifruit, which verifies Hypothesis 3 in our study to some extent. Surprisingly, the average yield of certified kiwifruit is higher than that of noncertified kiwifruit after matching. The result is not in line with our theoretical expectations. Therefore, Hypothesis 1 is not verified in our study.

Table 4. Average treatment effect on ATTs and critical value of Rosenbaum's $\Gamma$.

\begin{tabular}{|c|c|c|c|c|c|}
\hline $\begin{array}{l}\text { Propensity Score } \\
\text { Matching Method }\end{array}$ & Mean Treated & Mean Control & ATT & S.E. & $\Gamma^{\dagger}$ \\
\hline \multicolumn{6}{|l|}{ Economic outcomes: } \\
\hline Total revenue & 3082.224 & 2117.145 & 965.08 & 651.19 & 1.4 \\
\hline Total cost & 1234.208 & 920.804 & $313.40 * *$ & 147.51 & 1.7 \\
\hline Net income & 1848.015 & 1196.341 & 651.67 & 613.83 & 1.2 \\
\hline Sales price & 4.205 & 3.874 & 0.33 & 0.68 & 1.0 \\
\hline Average yield & 617.853 & 564.586 & 53.27 & 128.66 & 1.0 \\
\hline Employee cost & 59.667 & 8.156 & $51.51 *$ & 27.32 & 1.2 \\
\hline \multicolumn{6}{|c|}{ Environmental outcomes: } \\
\hline Farmyard manure & 157.937 & 91.071 & 66.87 & 56.24 & 1.0 \\
\hline Chemical fertilizer & 598.291 & 470.352 & 127.94 & 95.53 & 1.0 \\
\hline Pesticide & 62.896 & 67.586 & -4.69 & 14.48 & 1.0 \\
\hline
\end{tabular}

Table 4 also presents results for the environmental outcomes: Farmyard manure, Chemical fertilizer, and Pesticide. However, none of the matching estimators generate a significant ATT. The results provide much weaker evidence to verify Hypothesis 4. According to China's green food fertilizer application guideline, chemical fertilizer is allowed in Grade A green food produce while it is absolutely forbidden in Grade AA green food produce. The certified kiwifruit involved in this study is only Grade A green food produce. When the certified growers realize that they can use chemical fertilizer to improve the yield and obtain higher total revenues, they would be more likely to do so.

We calculated the critical value of $\Gamma^{\dagger}$ (Table 4, column 6). It alters the results of our statistical inference at the $10 \%$ level in each case. For the significant ATTs, the value of $\Gamma^{\dagger}$ of Total cost and Employee cost are 1.7 and 1.2, respectively. It implies that matched kiwifruit growers with the same observed covariates would have to differ in terms of unobserved covariates by a factor of 1.7 for Total cost and a factor of 1.2 for Employee cost to invalidate the inference of a significant treatment effect. Therefore, we conclude that the impact estimates are fairly robust to potentially hidden bias. (Apel et al. 
reported that the estimation results in applied research often become sensitive to an $\Gamma$ value as small as 1.15 [39].) However, the results are sensitive to unobserved characteristics of other insignificant ATTs.

\subsection{The Determinants of Production Behavior}

\subsubsection{The Determinants of Production}

Table 5 shows the results of the yield per mu function of kiwifruit of matched certified and noncertified growers. It can be concluded that, currently, the sum of production elasticity with respect to all inputs is less than 1 for both matched certified growers $\left(\sum_{i=1}^{i} \alpha_{i}=0.876\right)$ and noncertified growers $\left(\sum_{i=1}^{i} \alpha_{i}=0.826\right)$, indicating that kiwifruit production is in the state of decreasing returns to scale, that is, a $1 \%$ increase in all factors inputs would lead to an increase in output of less than $1 \%$. This may result from the fact that green food producers are more aware and have knowledge of such agricultural practices (sometimes labor-consuming but not necessarily requiring extensive use of agricultural chemicals) which assure higher crops than the ones in conventional farming. However, the value of the production elasticity of green food certified kiwifruit is greater than that of noncertified counterparts, implying that certified growers may have greater potential to increase yield than noncertified growers. The results may verify the alternative hypothesis of Hypothesis 1 in our study. We found that the additional chemical fertilizer inputs increased the yield of the noncertified growers, while the additional machinery operating inputs had a positive impact on the yield of the certified growers. The coefficient of chemical fertilizer of noncertified growers is significant, and the value of the coefficient of noncertified growers $(0.378)$ is greater than that of certified growers (0.201), implying that the additional chemical fertilizer inputs play a very important role in increasing yield of the noncertified growers at present. The coefficient of machinery operating inputs variable ( $\left.L n \_m a c h i n e\right)$ is significantly positive for certified growers but insignificant for noncertified growers. We found that certified growers have significantly larger cultivated areas than noncertified growers, resulting in more machinery operating inputs. On the other hand, certified farmers need to adopt green food certified kiwifruit planting standards (i.e., land consolidation, furrowing, ridging, and pruning), and accordingly, the machinery operating inputs may increase. Furthermore, farmyard manures inputs, pesticide inputs, and employee labor inputs had an insignificant impact on the yield of both certified growers and noncertified growers in our sample.

Table 5. Estimation results of the yield per mu function between matched certified and noncertified growers.

\begin{tabular}{|c|c|c|c|c|}
\hline \multirow[t]{2}{*}{ Variables } & \multicolumn{2}{|c|}{$\begin{array}{l}\text { The Certified Growers } \\
\qquad(n=56)\end{array}$} & \multicolumn{2}{|c|}{$\begin{array}{l}\text { The Noncertified Growers } \\
\qquad(n=241)\end{array}$} \\
\hline & Coefficient & S. E. & Coefficient & S. E. \\
\hline Ln_manure & -0.015 & 0.091 & 0.025 & 0.047 \\
\hline Ln_fertilizer & 0.201 & 0.257 & $0.378 * * *$ & 0.112 \\
\hline Ln_pesticide & -0.252 & 0.306 & 0.128 & 0.118 \\
\hline Ln_machine & $0.523^{* *}$ & 0.224 & 0.171 & 0.115 \\
\hline Ln_employ & 0.152 & 0.122 & 0.124 & 0.088 \\
\hline Age of head & 0.019 & 0.027 & $-0.029 * *$ & 0.012 \\
\hline Education of head & -0.056 & 0.112 & -0.024 & 0.041 \\
\hline Average area & -0.642 & 0.463 & $0.578^{* *}$ & 0.253 \\
\hline Tree age & $0.437^{* * *}$ & 0.111 & $0.198^{* * *}$ & 0.035 \\
\hline Agrimaterial store & -0.186 & 0.173 & $0.281^{* * *}$ & 0.086 \\
\hline Terrain & -0.525 & 1.390 & $-0.932 * *$ & 0.427 \\
\hline Constant & 0.806 & 2.639 & $1.980^{* *}$ & 0.994 \\
\hline $\mathrm{R}^{2}$ & \multicolumn{2}{|c|}{0.444} & \multicolumn{2}{|c|}{0.359} \\
\hline Adj.- $R^{2}$ & \multicolumn{2}{|c|}{0.305} & \multicolumn{2}{|c|}{0.338} \\
\hline
\end{tabular}

Notes: The nearest neighbor 1-to-1 matching method with replacement was used in our study. ${ }^{* * *}$ and ${ }^{* *}$ are significant at $1 \%$ and $5 \%$ level, respectively. 
Table 5 also presents other factors that influence the yield of kiwifruit between certified and noncertified growers. The coefficients of tree age variables (Tree age) are significantly positive for both certified and noncertified growers. However, the coefficient value of tree age of certified growers is greater than that of noncertified growers. The results show that the impact of tree age on the yield increase of certified growers is greater than that of noncertified counterparts. In addition, it can conclude that for noncertified growers, average and agricultural material stores have significant positive impact on the yield of kiwifruit, while age of farm head and farm terrain have significant negative impact on the yield of kiwifruit.

\subsubsection{The Determinants of Net Income}

Table 6 shows the results of the net income per mu function of kiwifruit for certified and noncertified growers. We found that both the coefficients of average yield variable (Average yield) and sales price (Sales price) variable are significantly positive, suggesting that the higher the average yield and sales price of kiwifruit, the higher the net income per mu. On the other hand, it is shown that both average yield variable (Average yield) and sales price (Sales price) variable have a higher impact on the net income of certified growers than that of noncertified growers. For example, holding other variables constant, when the market sales price of kiwifruit rose by 1 yuan, certified growers' net income per mu would increase by 578.017 yuan; however, in the same situation, the net income per mu of noncertified growers would increase by 399.257 yuan. Furthermore, we found that the coefficient of the sales channel variable (Sales channel) is significantly negative for certified growers but insignificant for noncertified growers. It indicates that certified kiwifruit is mainly sold outside the province and brings more net income to certified growers. This also reflects the strong extra provincial market potential of green kiwifruit compared with the traditional kiwifruit. However, we also found that the other three variables, Cooperative, Single decision, and Technical title are insignificant to both certified and noncertified growers.

Table 6. Estimation results of the net income per mu function of matched certified and noncertified growers.

\begin{tabular}{lcccc}
\hline \multicolumn{1}{c}{ Variables } & \multicolumn{2}{c}{$\begin{array}{c}\text { The Certified Growers } \\
(\boldsymbol{n}=\mathbf{5 6})\end{array}$} & $\begin{array}{c}\text { The Noncertified Growers } \\
(\boldsymbol{n}=\mathbf{2 4 1})\end{array}$ \\
\hline & Coefficient & S. E. & Coefficient & S. E. \\
\hline Average yield & $3.221^{* * *}$ & 0.388 & $2.496^{* * *}$ & 0.145 \\
Sales price & $578.017^{* * *}$ & 69.107 & $399.257^{* * *}$ & 31.281 \\
Sales channel & $-866.841^{* *}$ & 322.438 & -200.948 & 171.251 \\
Cooperative & -509.625 & 327.180 & -143.878 & 176.900 \\
Single decision & -150.426 & 341.647 & 91.498 & 181.301 \\
Technical title & 630.33 & 593.237 & 375.111 & 263.562 \\
Constant & -2006.445 & 385.038 & -1650.108 & 192.913 \\
$\mathrm{R}^{2}$ & \multicolumn{2}{c}{0.836} & \multicolumn{2}{c}{0.686} \\
Adj.- $^{2}$ & \multicolumn{2}{c}{0.816} & \multicolumn{2}{c}{0.678} \\
\hline
\end{tabular}

Notes: The nearest neighbor 1-to-1 matching method with replacement was used in our study. ${ }^{* * *}$ and ${ }^{* *}$ are significant at $1 \%$ and $5 \%$ level, respectively.

Of course, the certified kiwifruit growers run more risk than noncertified kiwifruit growers. This is particularly true for market risk, such as the fluctuations of selling price, which will significantly impact the sustainable development of the certified kiwifruit growers. In our study, for example, assuming that the selling price of green food drops from 4.12 yuan per $\mathrm{kg}$ to 3.49 yuan per $\mathrm{kg}$, which is consistent with the price of conventional food, while other variables remain constant, we find that the total revenue of green foods drops from 2601.149 yuan per mu $(4.21$ yuan $/ \mathrm{kg} \times 617.85 \mathrm{~kg} / \mathrm{mu}$ (in our case, the mean of average yield of green food is $617.85 \mathrm{~kg} / \mathrm{mu}$, while the mean of average yield of conventional food is $637.47 \mathrm{~kg} / \mathrm{mu})$ ) to 2156.297 yuan per mu (3.49 yuan $/ \mathrm{kg} \times 617.85 \mathrm{~kg} / \mathrm{mu}$ ), 
while the total revenue of conventional foods is 2224.77 yuan per $\mathrm{mu}(3.49$ yuan $/ \mathrm{kg} \times 637.47 \mathrm{~kg} / \mathrm{mu})$, which is higher than that of green foods. Therefore, if the selling price cannot be guaranteed high enough, overall profitability and durability of green food will be significantly affected.

\section{Conclusions}

In this paper, we first examined the economic and environmental benefits of participation in green food certified kiwifruit production. Second, we uncovered the differences between certified kiwifruit growers and noncertified growers. Third, based on the results of Cobb-Douglas production and profit function, we concluded the potential advantages of green certified kiwifruit production and basic conditions for its sustainable development.

Our findings suggest that certification has significant effects on economic outcomes but not on environmental outcomes. In terms of economic outcomes (Total cost and Employee cost), in each case, our matching estimators generated a positive and significant ATT that was robust against possible hidden bias. With regard to environmental outcomes, none of them had a significant effect. We also found that green food certified growers have higher machinery operating costs and younger tree ages of kiwifruit and thus experience an increase in average yield per mu than their matched counterparts. Furthermore, higher average yield and sales price, as well as appropriate marketing channels, result in improved net kiwifruit income per mu for green food certified growers. Also, green food certified growers have a higher net income per mu of kiwifruit than matched noncertified growers. However, the overall profitability and durability of green food will be seriously affected, unless the selling price is guaranteed to be reasonable and stable.

The potential advantages of green certified kiwifruit products and basic conditions for its sustainable development can be summed as follows: First, green food certification schemes can guarantee a product's quality, and its products can be sold at a higher price, which is an effective way to upgrade agriculture. Second, green farming has higher marginal output and higher potential compared to traditional production. Third, chemical fertilizer and pesticide inputs should be used less in the green production process, which is a sustainable and environmentally friendly production mode.

We recommend that the policy focus of government should increase investments in the farm and business management of kiwifruit growers. First, we should strengthen supervision of the quality of green food certified agricultural products and protect the economic interests of certified growers. Second, we need to encourage producers to apply for green food certification and then raise their awareness of green production. Third, government regulators should perform regular spot checks on the products market and severely punish the sale of fake and inferior products. Fourth, they should improve the traceability mechanism of green certified foods and improve the market recognition of green food. Finally, they should strengthen the management of the consumer complaint mechanism and effectively resolve the problem of consumer complaints.

Finally, this study still has some limitations that can inspire future research. For example, our sample size is relatively small, and so future research can cover more participants to test the robustness of our findings. Our sample is only limited to green food certification, and for future research, organic food certification deserves attention, which is certified in terms of the EU regulations. It would be particularly interesting in relation to the export opportunities to the external markets such as Europe, the USA, and other countries. It is also worth underlining that in Central and Eastern Europe, the organic food market is dynamically increasing and the demand for imported organic food is relatively high.

Author Contributions: Conceptualization, R.L. and H.M.; Validation, R.L. and H.M.; Formal Analysis, R.L., Z.G. \& H.M.; Investigation, R.L. and G.Y., Resource, R.L. and G.Y.; Data Curation, R.L. and G.Y.; Writing-Original Draft Preparation, R.L. and Z.G.; Writing-Review \& Editing, R.L., Z.G. \& H.M.; Project Administration, R.L. and H.M.; Funding Acquisition, H.M.

Funding: This research was funded by National Natural Science Foundation of China (Grant No. 71403082); Specialized Research Fund for the Jointed Doctoral Program of Higher Education of China (Grant No. 
20124105110006); Ministry of Education of Humanities and Social Science Research Project of China (Grant No. 14YCJ790080); Annual Scientific and Technological Innovation of Henan Province Talent Support Program (Grant No. 2017-cxrc-002); Young Backbone Teachers Scheme of Henan Colleges and Universities (Grant No. 2015GGJS-085); Henan Province Philosophy and Social Science Planning Project (Grant No. 2017BJJ033); Henan Provincial Department of Education Humanities and Social Sciences Research Project (Grant No. 2019-ZZJH-327); China Scholarship Council.

Conflicts of Interest: The authors declare no conflict of interest.

\section{References}

1. Scott, S.; Si, Z.; Schumilas, T.; Chen, A. Contradictions in state-and civil society-driven developments in China's ecological agriculture sector. Food Policy 2014, 45, 158-166. [CrossRef]

2. Mishra, A.K.; Kumar, A.; Joshi, P.K.; D'Souza, A.; Tripathi, G. How can organic rice be a boon to smallholders? Evidence from contract farming in India. Food Policy 2018, 75, 147-157. [CrossRef]

3. Thiers, P. China and global organic food standards: Sovereignty bargains and domestic politics. In Agricultural Standards: The Shape of the Global Food and Fiber System; Springer: Dordrecht, The Netherlands, 2006; pp. 193-217.

4. Sanders, R. A market road to sustainable agriculture? Ecological agriculture, green food and organic agriculture in China. Dev. Chang. 2006, 1, 201-226. [CrossRef]

5. Yu, X.; Gao, Z.; Zeng, Y. Willingness to pay for the "green food" in China. Food Policy 2014, 45, 80-87. [CrossRef]

6. Lin, L.; Zhou, D.; Ma, C. Green food industry in China: Development, problems and policies. Renew. Agric. Food Syst. 2009, 1, 69-80. [CrossRef]

7. Veeck, A.; Yu, H.; Burns, A.C. Consumer risks and new food systems in urban China. J. Macromark. 2010, 3, 222-237. [CrossRef]

8. Shi, Y.; Cheng, C.; Lei, P.; Wen, T.; Merrifield, C. Safe food, green food, good food: Chinese community supported agriculture and the rising middle class. Int. J. Agric. Sustain. 2011, 4, 551-558. [CrossRef]

9. Suki, N.M.; Suki, N.M. Does religion influence consumers' green food consumption? Some insights from Malaysia. J. Consum. Mark. 2015, 7, 551-563. [CrossRef]

10. Meas, T.; Hu, W.; Batte, M.T.; Woods, T.A.; Ernst, S. Substitutes or complements? Consumer preference for local and organic food attributes. Am. J. Agric. Econ. 2015, 4, 1044-1071. [CrossRef]

11. Bazzani, C.; Caputo, V.; Nayga, J.R.M.; Canavari, M. Revisiting consumers' valuation for local versus organic food using a non-hypothetical choice experiment: Does personality matter? Food Qual. Prefer. 2017, 62, 144-154. [CrossRef]

12. Valkila, J. Fair trade organic coffee production in Nicaragua-Sustainable development or a poverty trap? Ecol. Econ. 2009, 68, 3018-3025. [CrossRef]

13. Ruben, R.; Fort, R. The impact of Fair Trade certification for coffee farmers in Peru. World Dev. 2012, 3, 570-582. [CrossRef]

14. Rueda, X.; Thomas, N.E.; Lambin, E.F. Eco-certification and coffee cultivation enhance tree cover and forest connectivity in the Colombian coffee landscapes. Reg. Environ. Chang. 2015, 1, 25-33. [CrossRef]

15. Ibanez, M.; Blackman, A. Is eco-certification a win-win for developing country agriculture? Organic coffee certification in Colombia. World Dev. 2016, 82, 14-27. [CrossRef]

16. Philpott, S.; Bichier, P.; Rice, R.; Greenberg, R. Field testing ecological and economic benefits of coffee certification programs. Conserv. Biol. 2017, 21, 975-985. [CrossRef]

17. Martínez-Sánchez, J.C. The Role of Organic Production in Biodiversity Conservation In Shade Coffee Plantations; University of Washington: Seattle, WA, USA, 2008.

18. Kleemann, L.; Abdulai, A. Organic certification, ago-ecological practices and return on investment: Evidence from pineapple producers in Ghana. Ecol. Econ. 2013, 93, 330-341. [CrossRef]

19. Takahashi, R.; Todo, Y. Coffee certification and forest quality: Evidence from a wild coffee forest in Ethiopia. World Dev. 2017, 92, 158-166. [CrossRef]

20. Bolwig, S.; Gibbon, P.; Jones, S. The economics of smallholder organic contract farming in tropical Africa. World Dev. 2009, 6, 1094-1104. [CrossRef]

21. Chiputwa, B.; Spielman, D.J.; Qaim, M. Food standards, certification, and poverty among coffee farmers in Uganda. World Dev. 2015, 66, 400-412. [CrossRef] 
22. Jaffee, D. 2008. Better, but not great: The social and environmental benefits and limitations of fair trade for indigenous coffee producers in Oaxaca, Mexico. In The Impact of Fair Trade; Wageningen Academic Publishers: Wageningen, The Netherlands, 2008; pp. 196-222.

23. Blackman, A.; Naranjo, M.A. Does eco-certification have environmental benefits? Organic coffee in Costa Rica. Ecol. Econ. 2012, 83, 58-66. [CrossRef]

24. Weber, J.G. How much more do growers receive for Fair Trade-organic coffee? Food Policy 2011, 36, 678-685. [CrossRef]

25. Beuchelt, T.D.; Zeller, M. Profits and poverty: Certification's troubled link for Nicaragua's organic and fairtrade coffee producers. Ecol. Econ. 2011, 70, 1316-1324. [CrossRef]

26. Uematsu, H.; Mishra, A. Organic farmers or conventional farmers: Where's the money? Ecol. Econ. 2012, 78, 55-62. [CrossRef]

27. Crowder, D.W.; Reganold, J.P. Financial competitiveness of organic agriculture on a global scale. Proc. Natl. Acad. Sci. USA 2015, 24, 7611-7616. [CrossRef] [PubMed]

28. Thiers, P. From grassroots movement to state-coordinated market strategy: The transformation of organic agriculture in China. Environ. Plan. C Gov. Policy 2002, 3, 357-373. [CrossRef]

29. Blackman, A.; Rivera, J. Producer-level benefits of sustainability certification. Conserv. Biol. 2011, 25, 1176-1185. [CrossRef] [PubMed]

30. Mendez, V.E.; Bacon, C.M.; Olson, M.; Petchers, S.; Herrador, D.; Carranza, C.; Trujillo, L.; Guadarrama-Zugasti, C.; Cordón, A.; Mendoza, A. Effects of Fair Trade and organic certifications on small-scale coffee farmer households in Central America and Mexico. Renew. Agric. Food Syst. 2010, 25, 236-251. [CrossRef]

31. Rosenbaum, P.R.; Rubin, D.B. The central role of the propensity score in observational studies for causal effects. Biometrika 1983, 1, 41-55. [CrossRef]

32. Heckman, J.J.; Ichimura, H.; Smith, J.; Todd, P. Characterizing selection bias using experimental data. Econometrica 1998, 66, 1017-1098. [CrossRef]

33. Lechner, M. Program heterogeneity and propensity score matching: An application to the evaluation of active labor market policies. Rev. Econ. Stat. 2002, 2, 205-220. [CrossRef]

34. Dehejia, R.H.; Wahba, S. Propensity score-matching methods for nonexperimental causal studies. Rev. Econ. Stat. 2002, 1, 151-161. [CrossRef]

35. DiPrete, T.A.; Gangl, M. Assessing bias in the estimation of causal effects: Rosenbaum bounds on matching estimators and instrumental variables estimation with imperfect instruments. Sociol. Methodol. 2004, 34, 271-310. [CrossRef]

36. Becker, S.; Caliendo, M. Mhbounds-sensitivity analysis for average treatment effects. Stata J. 2007, 1, 71-83. [CrossRef]

37. Cobb, C.W.; Douglas, P.H. A theory of production. Am. Econ. Rev. 1928, 18, 139-165.

38. Durlauf, S.N.; Blume, L.E. The New Palgrave Dictionary of Economics, 2nd ed.; Macmillan Publishers Ltd.: London, UK, 2008; p. 862.

39. Apel, R.; Blokland, A.A.J.; Nieuwbeerta, P.; van Schellen, M. The impact of imprisonment on marriage and divorce: A risk set matching approach. J. Quant. Criminol. 2010, 2, 269-300. [CrossRef]

(C) 2018 by the authors. Licensee MDPI, Basel, Switzerland. This article is an open access article distributed under the terms and conditions of the Creative Commons Attribution (CC BY) license (http://creativecommons.org/licenses/by/4.0/). 